\title{
Subtidal macrozoobenthos communities from northern Chile during and post El Niño 1997-1998
}

\author{
Rodrigo A. Moreno • Roger D. Sepúlveda • Ernesto I. Badano • \\ Sven Thatje $\cdot$ Nicolás Rozbaczylo $\cdot$ Franklin D. Carrasco
}

Received: 30 May 2007 / Revised: 2 October 2007 / Accepted: 3 October 2007 / Published online: 27 November 2007

(C) Springer-Verlag and AWI 2007

\begin{abstract}
Despite a large amount of climatic and oceanographic information dealing with the recurring climate phenomenon El Niño (EN) and its well known impact on diversity of marine benthic communities, most published
\end{abstract}

Communicated by S. Thatje.

Special issue: Climate variability and El Niño Southern Oscillation: implications for natural coastal resources and management. S. Thatje (ed.).

R. A. Moreno $(\bowtie)$

Departamento de Ciencias Ecológicas and Instituto Milenio de Ecología y Biodiversidad (IEB), Facultad de Ciencias,

Universidad de Chile, Casilla 653, Santiago, Chile

e-mail: romoren@bio.puc.cl

R. D. Sepúlveda

Instituto de Ecología y Evolución, Facultad de Ciencias,

Universidad Austral de Chile, Casilla 567, Valdivia, Chile

\section{E. I. Badano}

Departamento de Ciencias Químico Biológicas,

Escuela de Ingeniería y Ciencias,

Universidad de las Américas-Puebla, Santa Catarina Martir,

Cholula, 72820 Puebla, México

S. Thatje

National Oceanography Centre, Southampton,

School of Ocean and Earth Science, University of Southampton,

European Way, Southampton SO14 3ZH, UK

\section{N. Rozbaczylo}

Departamento de Ecología, Facultad de Ciencias Biológicas, Pontificia Universidad Católica de Chile,

Casilla 114-D, Santiago, Chile

\section{F. D. Carrasco}

Departamento de Oceanografía,

Facultad de Ciencias Naturales y Oceanográficas,

Universidad de Concepción, Casilla 160-C, Concepción, Chile data are rather descriptive and consequently our understanding of the underlying mechanisms and processes that drive community structure during EN are still very scarce. In this study, we address two questions on the effects of EN on macrozoobenthic communities: (1) how does EN affect species diversity of the communities in northern Chile? and (2) is EN a phenomenon that restarts community assembling processes by affecting species interactions in northern Chile? To answer these questions, we compared species diversity and co-occurrence patterns of soft-bottoms macrozoobenthos communities from the continental shelf off northern Chile during (March 1998) and after (September 1998) the strong EN event 1997-1998. The methods used varied from species diversity and species cooccurrence analyses to multivariate ordination methods. Our results indicate that EN positively affects diversity of macrozoobenthos communities in the study area, increasing the species richness and diversity and decreasing the species dominance. EN represents a strong disturbance that affects species interactions that rule the species assembling processes in shallow-water, sea-bottom environments.

Keywords ENSO - Feeding mode .

Humboldt current system - Macrobenthic soft-bottom assemblages · Species co-occurrence · Southeastern Pacific

\section{Introduction}

El Niño Southern Oscillation (ENSO) is a recurrent, interannual climate variability characterized by an interaction between sea surface temperature (SST) and atmospheric pressure (Philander 1990; Fiedler 2002). This interaction between the tropical Pacific Ocean and the overlaying global atmosphere is the most important oceanographic climate 
phenomenon affecting physicochemical processes and biota in both marine and terrestrial ecosystems of western South America (Cowles et al. 1977; Barber and Chavez 1983; Dayton et al. 1999; Jaksic 2001). The coastal upwelling zone of the Humboldt current system (HCS) in the south-eastern Pacific is subject to strong variability during El Niño (the oceanographic component of ENSO) events (e.g., 19821983, 1997-1998), where this phenomenon has an important role as disturber agent causing modifications in the coastal biota at different scales (e.g., Glynn 1988; Camus 1990; Arntz and Fahrbach 1996; Arntz et al. 2006; Vásquez et al. 2006). McPhaden (1999) suggested that 1997-1998 ENSO to be the strongest on record. According to some physical indices however, the biological impact of El Niño (hereafter EN) on northern Chile and South America in general was not as catastrophic as generally expected (Arntz et al. 2006; Laudien et al. 2007). This does not only hold true for softbottom communities (Laudien et al. 2007), but also for the pelagic ecosystem of the same area (Ulloa et al. 2001).

Despite the large amount of oceanographic climate information existing on this phenomenon (Philander 1990; Escribano et al. 2004; Dijkstra 2006; Nyenzi and Lefale 2006; Santos 2006, Sokolikhina et al. 2006), and its known impacts on the diversity of marine soft-bottom benthic communities of shallow zones in the HCS (Peru-Chile, e.g., Tarazona et al. 1985, 1988a, 1996; Gallardo 1985; Salzwedel et al. 1988; Arntz et al. 1991; Gutiérrez et al. 2000; Laudien et al. 2007), our knowledge of the mechanism and processes driving community structure during EN is still scarce.

Several studies on EN effects on subtidal macrozoobenthos communities inhabiting oxygen minimum zone (OMZ) off Chile and Peru (see Levin 2003; Helly and Levin 2004) suggest that increases in bottom temperature and oxygenation caused by EN lead to higher macrozoobenthic species richness, but also cause decreases in the numerical dominance of formerly highly abundant taxa (Arntz et al. 1985, 1991; Tarazona et al. 1988b, 1996; Arntz and Fahrbach 1996; Levin et al. 2002; Arntz et al. 2006). Given that species diversity (understood as an integrative measure of the number of species in a given site regarding to their relative abundances) is positively affected by increases in species richness, but negatively affected by increased species dominance (Stirling and Wilsey 2001), it could be hypothesized that species diversity of sublittoral coastal communities should raise during EN because of an increased number of species and/or a decreased species dominance within communities.

Regarding the effects of species interactions on the structure of biotic assemblages, biogeography theory proposes that species inhabiting a given locality should have co-adjusted niches to reduce interspecific competition by limited resources (Diamond 1975; Chase and Leibold 2003). This "community assembly rule" proposes that, in a landscape composed by multiple sites (islands or habitat patches), highly competing species must not co-occur, or at least co-occur less than expected by chance, across these sites (Diamond 1975; Fox 2001). This assembly rule assumes that, after assembling occurs, all niches of a given site are occupied, so that species interactions reach a steady state and communities reach their maximum diversity (Bush and Whittaker 1993; Badano et al. 2005). For deep-sea environments, Sanders (1968) highlighted earlier the importance of such competitive interactions in affecting species distribution, suggesting that such species interactions would lead to mature benthic communities composed by "biologically accommodated" (non-competing) species, which in turn would lead to high diversity (see also Dayton and Hessler 1972; Abele and Walters 1979). However, for terrestrial ecosystems, it has been shown that disturbances could move communities away from this interactive steady state, restarting the assembly processes and causing changes in the species co-occurrence patterns within communities (Badano et al. 2005). For macrozoobenthos communities of shallow and deep waters off Chile and Peru, changes in bottom temperatures and oxygen concentration associated to EN represent a strong disturbance (Arntz et al. 1985, 1991; Arntz and Fahrbach 1996; Tarazona et al. 1985, 1988b, 1996; Gallardo 1985; Gutiérrez et al. 2000; Gallardo et al. 2004). Thus, it could be proposed that EN may restart successional processes of sublittoral communities, which should be reflected in a change in the species co-occurrence patterns.

In this study, we report the results from two hypotheses proposed above and address two basic questions: (1) do species richness and diversity increase, while dominance decreases, in macrozoobenthos communities during an EN warm period? and (2) is the EN a phenomenon that restarts assembling processes in these communities leading to changes in species co-occurrence patterns? To answer these questions, we compare macrozoobenthos communities linked to environmental conditions during and after the strong EN event 1997-1998 from the continental shelf off northern Chile. We compare our information with the data reported by Quiroga et al. (1999) concerning the temporal variations of macrozoobenthos in Iquique Bay during a non-EN period, in order to demonstrate that the temporal changes in the oceanographic conditions and in the community structure of macrozoobenthos are due product of EN 1997-98 effects and not due to seasonal variations.

\section{Materials and methods}

Study area

This study was conducted at Iquique Bay $\left(20^{\circ} 11^{\prime} \mathrm{S}\right.$, $70^{\circ} 10^{\prime} \mathrm{W}$ ), at the continental shelf off northern Chile 
(Fig. 1). This bay covers an area of approximately $3 \mathrm{~km}^{2}$ and has an average depth of $35 \mathrm{~m}$. The area is characterized by the presence of weak winds with long calm periods; an anti-clockwise circulation pattern in the central part of the bay generates a gyre, with waters flowing towards the north and northeast as a consequence of the bathymetry (Alvial and Moraga 1986). The sediment structure has been classified principally as (1) coarse sands at the shoreline, (2) fine sands in the central part, and (3) very fine sands in the deep part (Quiroga et al. 1999). Between May 1997 and July 1998, sea surface of Iquique Bay displayed positive temperature anomalies, indicating the presence of an EN event (Fuenzalida et al. 1999). Sea surface temperatures showed two peaks during this period, a soft peak between May and August 1997, where temperatures positively deviated up to $3.6^{\circ} \mathrm{C}$ from the long-term mean, and a strong peak between December 1997 and May 1998, where temperature anomalies rose to $5.5^{\circ} \mathrm{C}$. After July 1998, these temperature anomalies were followed by a cold-water period, with a peak of minimum temperatures in September, where sea surface temperature reached $1.3^{\circ} \mathrm{C}$ (Fuenzalida et al. 1999).

\section{Sampling design}

Macrozoobenthos $(>0.5 \mathrm{~mm})$ sampling was conducted during two cruises aboard R/V ANTARES (Universidad

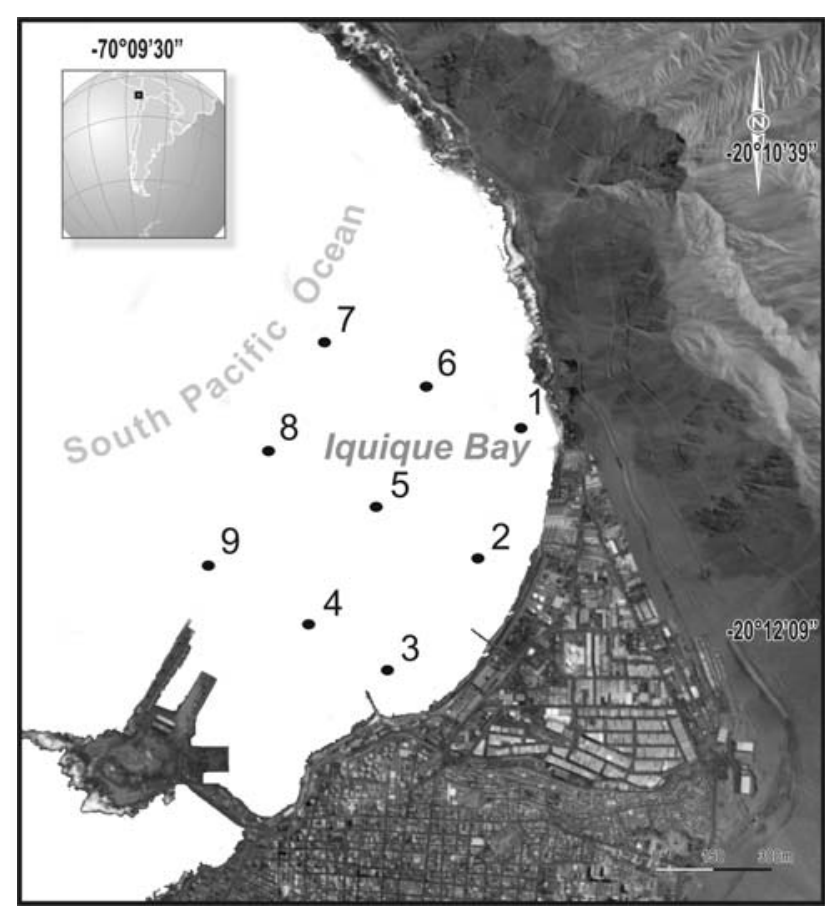

Fig. 1 Map indicating the position of the benthic sampling stations at Iquique Bay, northern Chile
Arturo Prat, Chile). Nine stations (S1-S9 in Fig. 1) were located at Iquique Bay (details in Table 1). At the beginning of March 1998 (during EN event) and at the end of September 1998 (after EN event), one sediment sample was collected with a Van Veen grab $\left(0.1 \mathrm{~m}^{2}\right)$ at each station. Samples were filtered using a geological sieve with $500 \mu \mathrm{m}$ mesh size, stored in plastic bags and fixed on board in $10 \%$ formalin. Because of technical difficulties in sampling benthos at station S2 during EN period, samples from this station were removed from all the analyses of species diversity and community structure, which were conducted with data from remaining eight stations.

In the laboratory, samples were stained with Bengal Rose and washed. For preservation of the biological material, the samples were saved in $70 \%$ ethanol until its later identification. Macrozoobenthos collected at each station was divided into major taxa and individuals were identified to the lowest taxonomic level possible with stereomicroscopes. Macrozoobenthos species were classified according to feeding groups following classifications proposed by Fauchald and Jumars (1979), Gaston (1987), Taghon and Greene (1992), and Levin et al. (1991, 1997, 1999) into nine major categories: carnivores, filter feeders, interface feeders, surface deposit feeders, subsurface deposit feeders, carnivore/surface deposit feeders (Opportunistic type 1), omnivore/carnivore (Opportunistic type 2), commensalist/surface deposit feeders (Opportunistic type 3 ), and filter feeder/surface deposit feeders (Opportunistic type 4).

Together with the sediment samples, we measured bottom water temperature $\left({ }^{\circ} \mathrm{C}\right)$ and obtained water samples from $0.5 \mathrm{~m}$ using Niskin bottles to assess dissolved oxygen content $\left(\mathrm{ml} \mathrm{O}_{2} / \mathrm{l}\right)$ during and after EN event. Dissolved oxygen above the bottom was measured following the modified Winkler's titration method (Strickland and Parsons 1972). Temperature and dissolved oxygen were compared between the two periods (during and after EN) with $t$-tests after log-transformation of the data (Zar 1999).

Species diversity analyses

To compare macrozoobenthos communities, we estimated species richness, diversity and dominance between the EN and the after-EN periods, with individual-based rarefaction techniques to avoid biases due to differences in sampling effort between sampling periods (Gotelli and Colwell 2001). Rarefaction analyses were performed with the software EcoSim 7.72 (Gotelli and Entsminger 2006). It is important to note that, in this rarefaction type, community attributes were estimated as sampling size $(\mathrm{SaS})$ increases, where each $\mathrm{SaS}$ was defined by sequentially increasing the number of individuals from 1 to $N$ (Gotelli and Colwell 
Table 1 Location, depth (m) and physical variables measured in the benthic sampling stations at Iquique Bay, northern Chile

\begin{tabular}{|c|c|c|c|c|c|c|c|}
\hline \multirow[t]{2}{*}{ Station } & \multirow[t]{2}{*}{ Latitude (S) } & \multirow[t]{2}{*}{ Longitude $(\mathrm{W})$} & \multirow[t]{2}{*}{ Depth (m) } & \multicolumn{2}{|l|}{ During EN } & \multicolumn{2}{|l|}{ After EN } \\
\hline & & & & Temperature $\left({ }^{\circ} \mathrm{C}\right)$ & Oxygen (ml/l) & Temperature $\left({ }^{\circ} \mathrm{C}\right)$ & Oxygen $(\mathrm{ml} / \mathrm{l})$ \\
\hline $\mathrm{S} 1$ & $20^{\circ} 11^{\prime} 28^{\prime \prime}$ & $70^{\circ} 08^{\prime} 45^{\prime \prime}$ & 8 & 16.7 & 2.36 & 9.8 & 1.32 \\
\hline $\mathrm{S} 2$ & $20^{\circ} 11^{\prime} 41^{\prime \prime}$ & $70^{\circ} 08^{\prime} 46^{\prime \prime}$ & 11 & 17.1 & 2.23 & 9.6 & 1.29 \\
\hline $\mathrm{S} 3$ & $20^{\circ} 12^{\prime} 26^{\prime \prime}$ & $70^{\circ} 08^{\prime} 55^{\prime \prime}$ & 9 & 17.4 & 2.38 & 10.3 & 2.19 \\
\hline $\mathrm{S} 4$ & $20^{\circ} 12^{\prime} 11^{\prime \prime}$ & $70^{\circ} 08^{\prime} 39^{\prime \prime}$ & 16 & 17.9 & 3.62 & 11.5 & 2.11 \\
\hline S5 & $20^{\circ} 11^{\prime} 56^{\prime \prime}$ & $70^{\circ} 08^{\prime} 29^{\prime \prime}$ & 17 & 18.1 & 3.5 & 11.8 & 1.98 \\
\hline S6 & $20^{\circ} 11^{\prime} 35^{\prime \prime}$ & $70^{\circ} 08^{\prime} 25^{\prime \prime}$ & 22 & 20.1 & 3.97 & 10.7 & 2.42 \\
\hline S7 & $20^{\circ} 11^{\prime} 50^{\prime \prime}$ & $70^{\circ} 09^{\prime} 18^{\prime \prime}$ & 29 & 22.7 & 3.03 & 11.9 & 2.49 \\
\hline S8 & $20^{\circ} 11^{\prime} 34^{\prime \prime}$ & $70^{\circ} 09^{\prime} 11^{\prime \prime}$ & 31 & 23.2 & 3.36 & 11.5 & 3.2 \\
\hline S9 & $20^{\circ} 11^{\prime} 18^{\prime \prime}$ & $70^{\circ} 09^{\prime} 48^{\prime \prime}$ & 33 & 21.6 & 3.43 & 11.8 & 2.18 \\
\hline
\end{tabular}

2001). In the analyses, we randomly selected 1,000 times a re-sample for each increasing $\mathrm{SaS}$ (from 1 to $N$ ) and estimated the number of species (species richness), the Shannon-Wiener diversity index, and the fraction of the collection that is represented by the most abundant species (a species dominance index) at each run. After 1,000 rarefaction runs were performed, species richness at each $\mathrm{SaS}$ was estimated as the average number of species calculated from the respective 1,000 re-samples obtained for each $\mathrm{SaS}$ (Gotelli and Entsminger 2006).

The Shannon-Wiener $H^{\prime}$ diversity index at each SaS was calculated using natural logarithms as $H^{\prime}=$ $\sum$ pi $\ln (\mathrm{pi})$, where pi $=$ proportion of individuals of the $i$ th species in the sample; then, these 1,000 values of this index obtained for each sampling were averaged to estimate the mean diversity of the respective SaS. The species dominance index, calculated as the fraction of the (re-sampled) collection that is represented by the most common species at each rarefaction run (Gotelli and Entsminger 2006) was estimated in the same way as described for the $H^{\prime}$ index. These average values of species richness, diversity, and dominance were plotted against their respective $\mathrm{SaS}$ to assess variations as the number of individuals included in the samples increased. In order to assess statistical differences between during and after-EN periods, we calculated the $95 \%$ confidence intervals for each community attribute at each SaS. Significant differences between periods were assumed if their confidence intervals did not overlap (Gotelli and Entsminger 2006).

Multivariate statistical analysis was performed on the abundance data square root transformed. Additionally, Bray-Curtis similarities were calculated (Bray and Curtis 1963). Multidimensional scaling (MDS) ordination was performed to identify if the replicates of each period are really strongly grouped (Shepard 1962; Kruskal 1964). Statistical differences were analyzed by means of an analysis of similarity (one-way ANOSIM, Clarke 1993). Species with the highest dominance on the soft-bottom in the northern Chile were identified by SIMPER procedure (similarity of percentage). All multivariate analyses were performed using PRIMER 5.2.2 computer package (Plymouth Routines in Multivariate Ecological Research).

Species co-occurrence analyses

To assess structural changes in macrozoobenthos communities because of species interactions during and after the EN event, we used the $C$-score (Stone and Roberts 1990, 1992) as a quantitative index of co-occurrence. The $C$ score is the average of "checkerboard units" calculated for all the species pairs that occur at least once in the sample pool. A checkerboard unit is any sub-matrix of form: $a$ or $b$

\begin{tabular}{lll}
\hline $\mathrm{a}$ & Sample 1 & Sample 2 \\
\hline Species 1 & 0 & 1 \\
Species 2 & 1 & 0 \\
\hline $\mathrm{b}$ & Sample 1 & Sample 2 \\
\hline Species 1 & 1 & 0 \\
Species 2 & 0 & 1 \\
\hline
\end{tabular}

The number of checkerboard units (CU) for each species pair is calculated as $\mathrm{CU}=\left(r_{\mathrm{i}}-S\right)\left(r_{\mathrm{j}}-S\right)$, where $r_{\mathrm{i}}$ and $r_{\mathrm{j}}$ are the numbers of sampling stations on which species $i$ and $j$ were detected, and $S$ is the number of sampling stations containing both species. Based on this index, to analyze the influence of the EN event on community structure, we first considered the whole community, including species from all feeding groups together. For this, a species co-occurrence matrix was constructed for both periods, where columns in the matrices were the sampling stations and rows the species. A $C$-score value 
was computed from each matrix and it was contrasted against a $C$-score expected by chance (i.e. the $C$-score value expected if interactions do not affect the species cooccurrence at sampling stations). These expected values were computed as the average $C$-score of 5,000 null communities simulated from the respective co-occurrence matrix. These were constructed placing species randomly and independently of one another with the software EcoSim 7.72 (Gotelli and Entsminger 2006). However, given that the strength of competition could depend on the local abundance of individuals (Connolly and Roughgarden 1999), the probability of a particular station being "hit" by a given species was weighted by the total abundance of individuals detected at each station. Similarly, given that highly abundant species are likely to be competitively superior than less abundant, rare species (Connolly and Roughgarden 1999), the probability of a particular species being present at a given station was weighted by the total abundance of each species. After calculating $C$-scores, EcoSim calculated the probability for the observed $C$-score to be higher than expected by chance. In competitively structured communities, the observed $C$-score are significantly higher than the $C$-score expected by chance (Stone and Roberts 1992).

Given that competitive interactions are more likely to occur between species with similar resource requirements, we also performed co-occurrence analyses separately for the five most common feeding groups detected in both sampling periods: carnivores, filter feeders, interface feeders, carnivore/surface deposit feeders (Opportunistic type 1), omnivore/carnivore (Opportunistic type 2). The aim behind these analyses was to identify what groups make major contributions to the observed co-occurrence pattern when the whole community, including all taxa and feeding groups, is considered.

\section{Results}

\section{Environmental variables}

Bottom temperatures and dissolved oxygen content were significantly higher during-EN than at the after-EN period (Temperature: $t_{(16)}=11.014, P<0.001$; Dissolved oxygen: $\left.t_{(16)}=3.298, \quad P=0.004\right)$. The average bottom temperature during $\mathrm{EN}$ was $19.42^{\circ} \mathrm{C}( \pm 0.84)$, while in the after-EN period the temperature decreased to $10.99^{\circ} \mathrm{C}$ $( \pm 0.30)$ (mean \pm S.E.). On the other hand, the average dissolved oxygen concentration during $\mathrm{EN}$ reached $3.10 \mathrm{ml} / 1( \pm 0.21)$, but decreased to $2.13 \mathrm{ml} / 1( \pm 0.20)$ in the after EN period (mean \pm S.E.). These results clearly indicate that EN event led to changes in bottom environmental conditions in the subtidal zone of Iquique Bay.
Species diversity

A total of 1,151 and 985 individuals were collected and identified during and after EN, respectively. During EN, a total of 49 species were recorded. Out of these, 19 species were not detected in the later after-EN period (Table 2). After EN, we recorded 40 species in total, where 9 of these species were not recorded in the previous period (Table 2).

The number of species raised as the number of individuals increased in both the sampling periods. Species richness was higher during than after EN, being statistically different after 650 individuals were analyzed (Fig. 2a), although an asymptotic flattening was not reached. The Shannon-Wiener diversity index also increased with the number of individuals and was higher during than after EN, but statistical differences between periods were detected at lower numbers of individuals (after 150 individuals) than for species richness (Fig. 2b). In contrast to the two latter, dominance remained constant across sampling sizes in both periods, but it was significantly lower during EN (Fig. 2c).

The MDS ordination showed that stations during EN were more separated than after EN, perhaps due to the major diversity showed during this period (Fig. 3). Oneway ANOSIM showed significant differences between the faunal compositions from each period $(R=0.26$; $P=0.005)$. The SIMPER analysis revealed that the polychaete Paraprionospio pinnata (Ehlers 1901) (25.65 and $52.39 \%$ ) and the mollusc Nassarius gayi (Kiener 1835) (11.33 and $20.74 \%$ ) were the most dominant species during and after EN 1997-1998 at Iquique Bay, respectively. The same analysis revealed that average dissimilarity between the two periods was $75.47 \%$, showing a low similarity of the species composition during and after EN.

\section{Species co-occurrence}

When all feeding groups were included on the species cooccurrence analyses, the observed $C$-score during EN event was significantly higher than its expected value assuming random distribution of species across sampling stations, indicating that species tend to avoid each other. Furthermore, during this EN period, co-occurrence analyses conducted separately for each feeding group indicated that species from all feeding groups tend to co-occur less than expected by chance (Fig. 4a). In contrast, after EN event, the observed $C$-score including all species showed no differences with its value expected by chance, indicating a random pattern of species co-occurrence. Indeed, with exception of filter feeders, $C$-scores for all the other feeding groups did not differ from values expected by chance, indicating that species within a given feeding group are distributed independently of the another one (Fig. 4b). 
Table 2 List of species recorded during and after the EN event 1997-1998

\begin{tabular}{|c|c|c|c|c|c|}
\hline Phylum & Family & Species & Feeding group & During EN & After EN \\
\hline Cephalochordata & Branchiostomatidae & Branchiostoma elongatum & FF & 44 & 1 \\
\hline Cnidaria & & Indeterminate species 1 & $\mathrm{FF}$ & 23 & 23 \\
\hline \multirow[t]{19}{*}{ Crustacea } & Ampeliscidae & Ampelisca sp. & SSDF & 0 & 1 \\
\hline & Alpheidae & Betaeus truncatus & Ot2 & 1 & 1 \\
\hline & Thalassinidae & Biffarius pacificus & Ot1 & 0 & 4 \\
\hline & Albuneidae & Blepharipoda spinimana & FF & 6 & 0 \\
\hline & Cancridae & Cancer edwarsi & Ot1 & 0 & 1 \\
\hline & Cancridae & Cancer setosus & Ot1 & 5 & 0 \\
\hline & Dyastilidae & Cyclaspis sp. & SSDF & 31 & 6 \\
\hline & Calappidae & Hepatus chilensis & Ot1 & 24 & 0 \\
\hline & Xanthidae & Homalaspis plana & Ot1 & 2 & 1 \\
\hline & Hippolytidae & Latreutes antiborealis & Ot2 & 0 & 1 \\
\hline & Calappidae & Mursia gaudichaudi & Ot1 & 2 & 0 \\
\hline & Nannosquillidae & Nannosquilla sp. & Ot1 & 1 & 0 \\
\hline & Ogyrididae & Ogyrides tarazonai & SSDF & 3 & 0 \\
\hline & Diogenidae & Paguristes weddelli & Ot1 & 14 & 0 \\
\hline & Paguridae & Pagurus perlatus & Ot1 & 1 & 0 \\
\hline & Paguridae & Pagurus villosus & Ot1 & 34 & 1 \\
\hline & Pinnotheridae & Pinnixa transversalis & Ot3 & 23 & 1 \\
\hline & Pinnotheridae & Pinnixa valdiviensis & Ot3 & 2 & 10 \\
\hline & Phoxocephalidae & Indeterminate species 2 & SSDF & 10 & 0 \\
\hline \multirow[t]{17}{*}{ Mollusca } & Arcidae & Barbatia sp. & FF & 57 & 11 \\
\hline & Calyptraeidae & Crepipatella dilatata & $\mathrm{FF}$ & 1 & 0 \\
\hline & Calyptraeidae & Crucibulum quiriquinae & FF & 1 & 48 \\
\hline & Cultellidae & Ensis macha & $\mathrm{FF}$ & 25 & 2 \\
\hline & Veneridae & Eurhomalea salinensis & $\mathrm{FF}$ & 8 & 0 \\
\hline & Glycymeridae & Glycymeris ovatus & $\mathrm{FF}$ & 0 & 7 \\
\hline & Tellinidae & Macoma inornata & $\mathrm{FF}$ & 0 & 1 \\
\hline & Columbellidae & Mitrella unifasciata & $\mathrm{C}$ & 56 & 73 \\
\hline & Montacutidae & Mysella sp. & SDF & 0 & 2 \\
\hline & Nassariidae & Nassarius dentifer & $\mathrm{C}$ & 14 & 7 \\
\hline & Nassariidae & Nassarius gayi & Ot2 & 128 & 180 \\
\hline & Olividae & Oliva peruviana & Ot2 & 2 & 1 \\
\hline & Naticidae & Polinices uber & $\mathrm{C}$ & 3 & 3 \\
\hline & Columbellidae & Salitra radwini & $\mathrm{C}$ & 6 & 6 \\
\hline & Solemyidae & Solemya sp. & $\mathrm{FF}$ & 1 & 0 \\
\hline & Muricidae & Xanthochorus buxea & $\mathrm{C}$ & 2 & 0 \\
\hline & Muricidae & Xanthochorus cassidiformis & $\mathrm{C}$ & 1 & 4 \\
\hline Nemertea & & Indeterminate species 3 & $\mathrm{C}$ & 29 & 9 \\
\hline \multirow[t]{9}{*}{ Polychaeta } & Phyllodocidae & Anaitides sp. & $\mathrm{Ot} 2$ & 0 & 2 \\
\hline & Paraonidae & Aricidea pigmentata & SDF & 8 & 40 \\
\hline & Onuphidae & Diopatra chiliensis & $\mathrm{Ot} 2$ & 13 & 42 \\
\hline & Spionidae & Dipolydora socialis & IF & 3 & 4 \\
\hline & Lumbrineridae & Eranno bifilaris & $\mathrm{Ot} 2$ & 0 & 6 \\
\hline & Glyceridae & Glycera americana & $\mathrm{Ot} 2$ & 1 & 0 \\
\hline & Goniadidae & Goniada peruana & $\mathrm{Ot} 2$ & 1 & 3 \\
\hline & Polynoidae & Halosydna sp. & $\mathrm{Ot} 2$ & 17 & 0 \\
\hline & Orbiniidae & Haploscoloplos kerguelensis chilensis & SSDF & 52 & 48 \\
\hline
\end{tabular}


Table 2 continued

\begin{tabular}{|c|c|c|c|c|c|}
\hline Phylum & Family & Species & Feeding group & During EN & After EN \\
\hline & Magelonidae & Magelona phyllisae & SSDF & 0 & 13 \\
\hline & Nephtyidae & Nephtys ferruginea & Ot2 & 23 & 22 \\
\hline & Nereididae & Nereis dorsolobata & Ot2 & 42 & 5 \\
\hline & Spionidae & Paraprionospio pinnata & IF & 382 & 384 \\
\hline & Spionidae & Prionospio peruana & IF & 10 & 4 \\
\hline & Spionidae & Rhynchospio glutaea & IF & 1 & 0 \\
\hline & Spionidae & Scolelepis chilensis & IF & 11 & 1 \\
\hline & Spionidae & Spiophanes bombyx & IF & 16 & 6 \\
\hline & Phyllodocidae & Indeterminate species 4 & Ot2 & 5 & 0 \\
\hline & Syllidae & Indeterminate species 5 & Ot2 & 5 & 0 \\
\hline & Sabellidae & Indeterminate species 6 & Ot4 & 1 & 0 \\
\hline Total number of individuals & & & & 1,151 & 985 \\
\hline Total number of species & & & & 49 & 40 \\
\hline
\end{tabular}

The table indicates the taxa, family, feeding group and the number of individuals collected of each species during and after EN. Species were classified into feeding groups: carnivores $(C)$, filter feeders $(F F)$, interface feeders $(I F)$, surface deposit feeders $(S D F)$, subsurface deposit feeders $(S S D F)$, carnivore/surface deposit feeders (Opportunistic type 1, Ot1), omnivore/carnivore (Opportunistic type 2, Ot2), commensalist/surface deposit feeders (Opportunistic type 3,Ot3), and filter feeder/surface deposit feeders (Opportunistic type 4, Ot4)

\section{Discussion}

Our results suggest that EN events can positively affect diversity of sublittoral macrozoobenthos communities in northern Chile, and that environmental anomalies associated with this phenomenon may affect species assembling processes. Positive effects of EN events on macrozoobenthos communities have been previously reported for the upwelling systems along the Peruvian coast (Tarazona 1984; Tarazona et al. 1985, 1988a, 1996; Arntz et al. 1991; Arntz and Fahrbach 1996; but see Yupanqui et al. 2007), north (Laudien et al. 2007) and central Chile (Gallardo 1985; Gutiérrez et al. 2000), and were generally suggested to be related with increased water temperature and dissolved oxygen during EN. However, as far as we are aware, no previous studies had reported the potential of this oceanographic anomaly to affect species assembling processes in marine benthic communities.

The high values of bottom temperatures and dissolved oxygen content recorded in the present study in Iquique Bay during EN match a previous report for the soft-bottom shallow waters at Ancon Bay $\left(11^{\circ} 46^{\prime} \mathrm{S}\right)$ off Peru affected by EN 1982-1983 (Tarazona 1984). Oceanographic conditions during EN are known to induce recolonization processes in hypoxic areas determining changes in abundance, biomass, and species richness in benthic communities (Tarazona 1984; Tarazona et al. 1985, 1988a, 1996). In addition, oceanographic changes of water masses circulation during EN contribute to immigration of species from equatorial warm waters to temperate waters of the HCS, as well as increased larval dispersal of species, thus extending their bathymetric and geographic distributions
(Tarazona 1984; Arntz and Fahrbach 1996; Tarazona et al. 1996). Accordingly, during EN 1997-1998, invasive predator species such as the portunid decapods Callinectes arcuatus Ordway, Areneus mexicanus (Gerstaecker) and the pelagic species Euphylax dowi Stimpson (Guzmán et al. 1999), the shrimps Farfantopenaeus californiensis (Holmes), Trachysalambria brevisuturae (Burkenroad), Sicyona disdorsalis (Burkenroad) and Solenocera mutator Burkenroad (Guzmán and Soto 2000), and the flatfish Etropus ectenes Jordan (Sielfeld et al. 2003), were recorded for Iquique Bay and coincide with our sampling period. On the other hand, compared with previous data from Quiroga et al. (1999) for a non-EN period at Iquique Bay, our results strongly support the effect of EN 1997-1998 on shallow-water, soft-bottom macrozoobenthos in this area. This is likely due to temporal changes in the oceanographic conditions inducing changes in benthic community structure in this bay.

The trophic structure of the macrozoobenthic community studied was dominated by interface feeding and omnivore/carnivore species (Opportunistic type 2) during and after EN 1997-1998. For both periods, polychaete worms and molluscs dominated the community at Iquique Bay. The polychaete Paraprionospio pinnata and the mollusc Nassarius gayi were the most dominant species. Our results are in accordance with previous studies for the upwelling systems of the Peruvian (Tarazona 1984; Tarazona et al. 1985, 1988a, 1996; Arntz et al. 1991; Yupanqui et al. 2007) and Chilean coast in the HCS affected by EN (Gallardo 1985; Gutiérrez et al. 2000; Laudien et al. 2007).

Differences in the values of the Shannon-Wiener diversity index $\left(H^{\prime}\right)$ during and after the EN event could be 

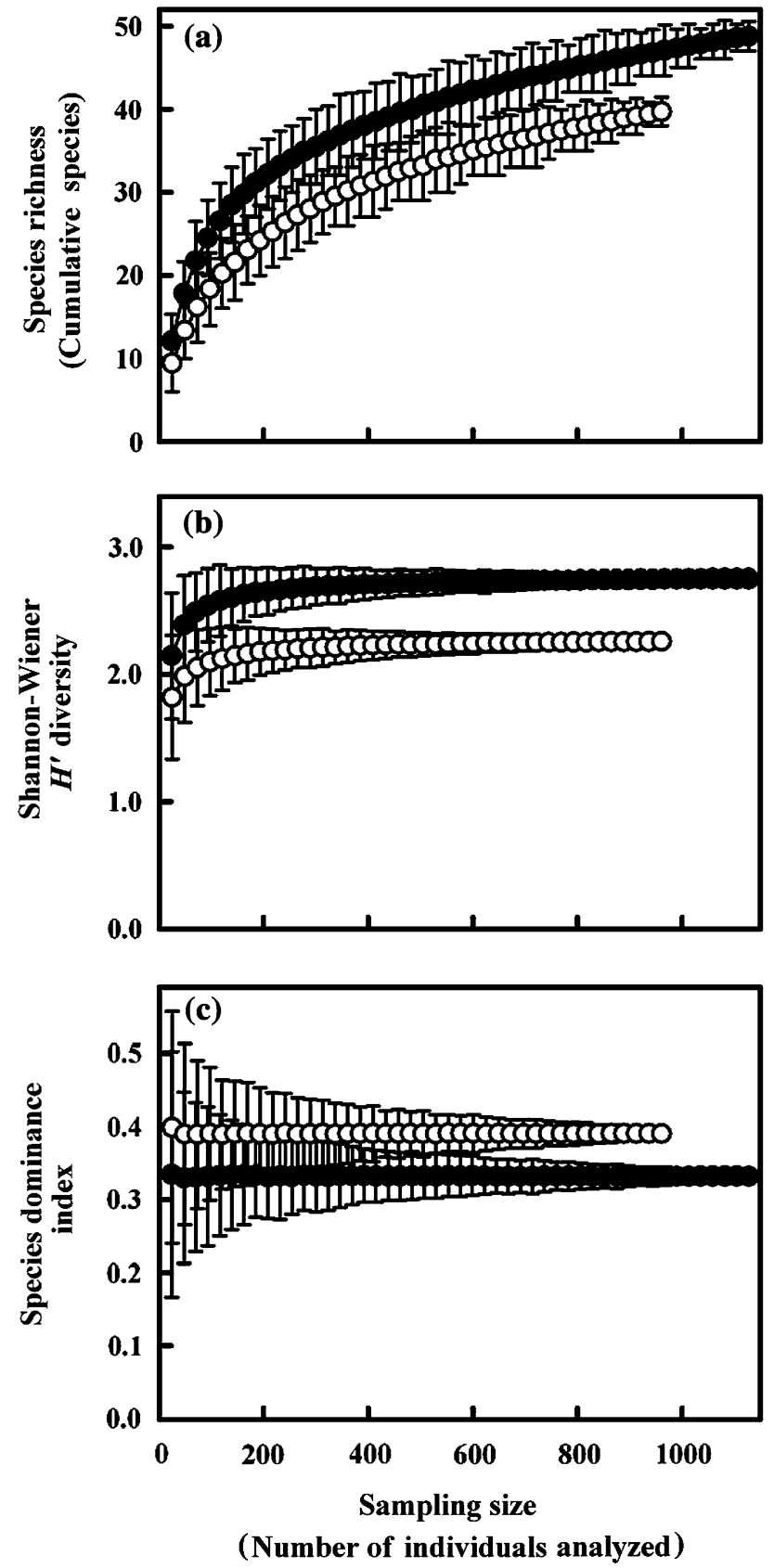

Fig. 2 Average values ( $\pm 95 \%$ confidence intervals) of species richness (a), Shannon-Wiener $H^{\prime}$ diversity index (b) and dominance (c) estimated as sampling size increased during (solid symbols) and after (empty symbols) EN 1997-1998. Significant differences were assumed if $95 \%$ confidence intervals did not overlap between the periods

related with the observed changes in species richness and species dominance. Theoretically, strong positive relationships exist between $H^{\prime}$ and increases in species richness, while negative relationships exist between $H^{\prime}$ and increased species dominance (DeBenedictis 1973; but see Stirling and Wilsey 2001 for detailed discussion). Thus, while the increase in richness and decrease in dominance

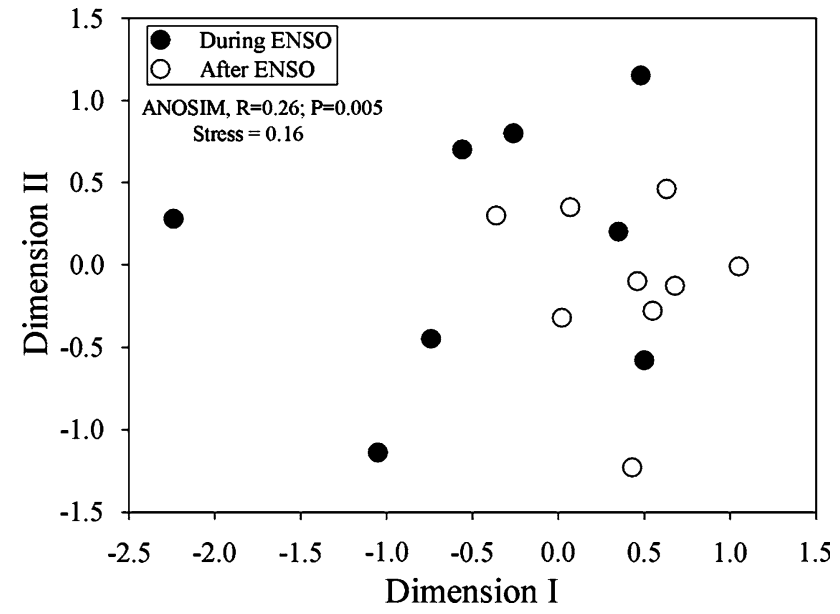

Fig. 3 Multidimensional scaling (MDS) plot resulting from ordination analysis (Bray-Curtis similarities) of macrozoobenthos from Iquique Bay, northern Chile, using abundance data. Most samples from after EN 1997-1998 (empty symbols) are more closely related and separated from the rest of the samples from during EN 19971998 period (solid symbols)

observed during EN event were responsible for the observed increase in diversity, in our case decreased richness and increased dominance after EN could account for reduced diversity (see Fig. 2). Similar changes in species richness, dominance and diversity of macrozoobenthos communities were detected from the continental shelf off Peru during the strong EN event 1982-1983. For instance, in shallow waters (12-22 m depth) off Peru, Tarazona et al. (1985) reported that values of species richness and diversity before EN were about half of the values observed during EN. Furthermore, for deeper waters close to the OMZ (34 m depth), Tarazona et al. (1988b) indicated that species richness and diversity both before and after EN 1982-1983 were lower than during EN, and also indicated a decrease in species evenness (higher evenness $=$ lower dominance) after EN. Thus, based on our results, we suggest that EN represents a strong disturber agent for macrozoobenthos communities, leading to higher local species diversity, where increased diversity could be linked with both increase in species richness and decrease in species dominance.

Co-occurrence analyses indicated that EN events might also influence the structure of macrozoobenthos communities of the continental shelf off northern Chile. The negative pattern of co-occurrence observed during EN indicates mutually exclusive distributions of macrozoobenthos species. In contrast, the random pattern of cooccurrence found after EN suggests that interspecific interactions would have little effect on community structure in this period. Furthermore, when co-occurrence analyses were conducted separately for each feeding group, species from all groups were indicated to have negative 


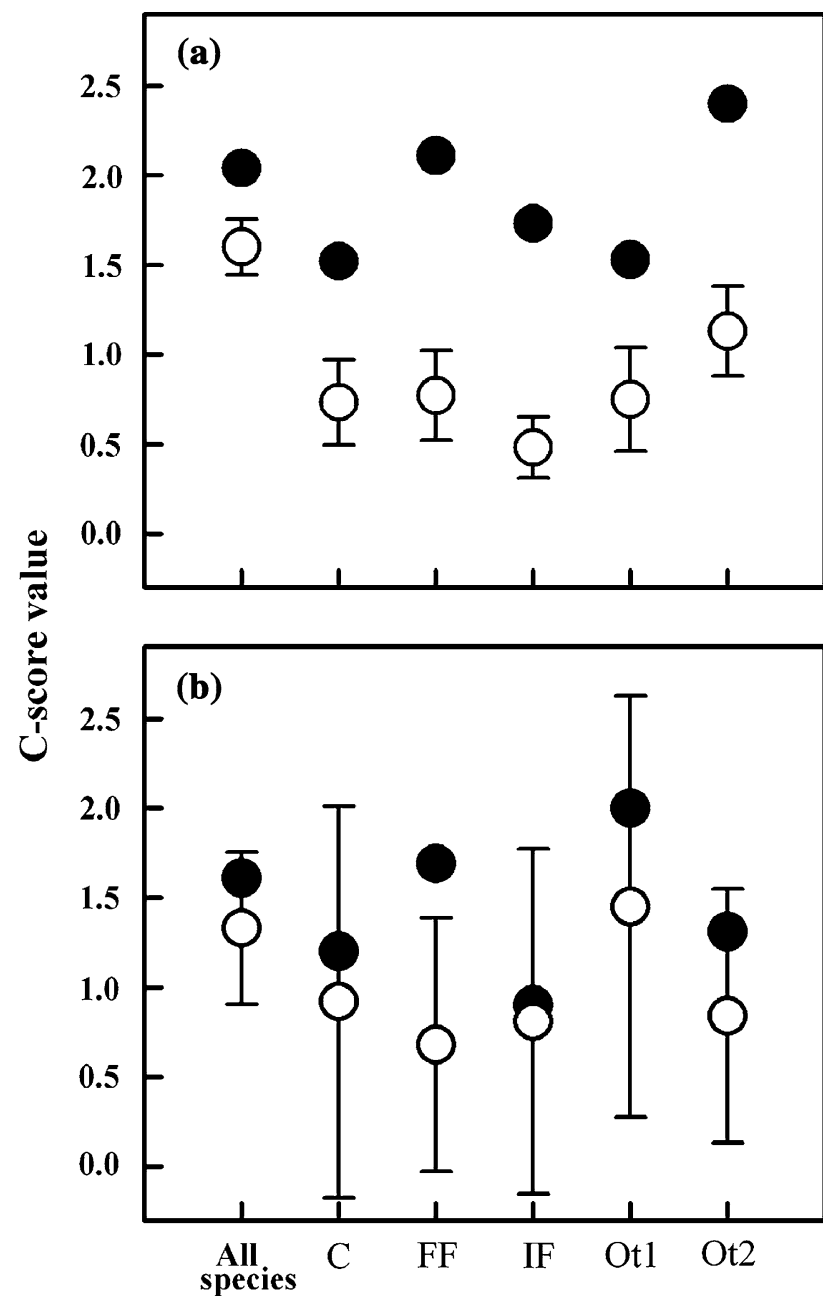

Fig. 4 Observed (solid symbols) and expected (empty symbols) Cscores $( \pm 95 \%$ confidence intervals) calculated by including species from all feeding groups together (All species) and separately for each feeding group during (a) and after (b) EN 1997-1998. If observed $C$ scores level off outside upper confidence interval limit of their respective $C$-score expected by chance, the observed value is significantly higher that the expected one (i.e., $P_{\text {(observed }}>$ expected) $<$ $0.05)$. Feeding groups are the same as in Table 2

patterns of co-occurrence during EN, suggesting strong competitive interactions among them, while only suspension feeders showed negative co-occurrence patterns after EN (Fig. 4). These differences in the patterns of species distribution between EN and after-EN suggest that this phenomenon may determine the importance of biotic interactions in structuring macrozoobenthos communities off northern Chile. Diamond (1975) proposed that mutually exclusive distributions of species across sites of a given region are caused by "forbidden species combinations". In other words, only certain species combinations can coexist at a given site, while other combinations never occur, or at least are much less common, because of competitive exclusion (Fox 2001). Our analyses suggest that certain species combinations would occur during EN, while this environmental anomaly seems to "reset" the macrozoobenthos community organization to a non-competitive stage.

Results showing higher species diversity when species co-occurrence patterns are negative seem to be counterintuitive, mainly because competitive interactions that cause negative co-occurrence patterns are assumed to decrease diversity (Huston 1979; McAuliffe 1984; Cerdá et al. 1998; Weiher and Keddy 2001). However, while it is feasible to think that species strongly compete during EN, it is also possible that sampling stations across the study area are being occupied by certain groups of non-competing species that can coexist. If so, while negative species co-occurrence patterns across the region suggest high interspecific competition, the high regional diversity (Fig. 2) could result from different species occupying different sites. Such patterns of species co-occurrence and diversity have been predicted and tested for organisms of terrestrial ecosystems (Whittam and Siegel-Causey 1981; Wilson 1992), but the hypothesis proposed here to account for the observed patterns of diversity and co-occurrence of macrozoobenthos communities may be useful to future experimental analyses.

Acknowledgments The authors are very grateful to Wolf E. Arntz, Marcelo M. Rivadeneira, and two referees for their valuable comments and suggestions that greatly improved the manuscript. We also thank Guillermo Guzmán, Cecilia Osorio, and Renán Peña for taxonomic assistance in organism identification. Rodrigo A. Moreno and Sven Thatje are supported by the EU-FP6-INCO-project CENSOR "Climate variability and El Niño Southern Oscillation: implications for natural coastal resources and management" (contract 511071) and this is CENSOR publication 0069. Rodrigo A. Moreno and Roger D. Sepúlveda were supported by CONICYT-Chile Doctoral Fellowships. Ernesto I. Badano thanks to FONDECYT 3060095 for support of the postdoctoral project, and grants FONDAP-FONDECYT 1501-0001 (CASEB) and ICM P05-002 (IEB). The first author dedicated this work to memory of the Marine Biologist Fernando Yañez who died recently in a diving accident in northern Chile.

\section{References}

Abele L, Walters J (1979) Marine benthic diversity: a critique and alternative explanation. J Biogeogr 6:115-126

Alvial H, Moraga J (1986) Estudio de la circulación de la Bahía Iquique $\left(20^{\circ} 12^{\prime} \mathrm{S} ; 70^{\circ} 10^{\prime} \mathrm{W}\right)$ usando derivadores. Invest Mar Valparaíso 14:17-33

Arntz WE, Fahrbach E (1996) El Niño: experimento climático de la naturaleza. Fondo de Cultura Económica, México DF

Arntz WE, Flores LA, Maldonado M, Carbajal G (1985) Cambios de los factores ambientales, macrobentos y bacterias filamentosas en la zona de mínimo de oxígeno frente al Perú durante "El Niño" 1982-1983. In: Arntz WE, Landa A, Tarazona J (eds) El Niño y su Impacto en la Fauna Marina. Instituto del Mar del Perú, Callao, pp 65-77

Arntz WE, Tarazona J, Gallardo VA, Flores LA, Salzwedel H (1991) Benthos communities in oxygen deficient shelf and upper slope 
areas of the Peruvian and Chilean Pacific coast, and changes caused by El Niño. In: Tyson RV, Pearson TH (eds) Modern and ancient continental shelf anoxia. Geol. Soc, Lond, pp 131-154

Arntz WE, Gallardo VA, Gutiérrez D, Isla E, Levin LA, Mendo J, Neira C, Rowe GT, Tarazona J, Wolff M (2006) El Niño and similar perturbation effects on the benthos of the Humboldt, California, and Benguela current upwelling ecosystems. Adv Geosci 6:243-265

Badano EI, Regidor HA, Núñez HA, Acosta R, Gianoli E (2005) Species richness and structure of ant communities in a dynamic archipelago: effect of island area and age. J Biogeogr 32:221227

Barber RT, Chavez FP (1983) Biological consequences of El Niño. Science 222:1203-1210

Bray JR, Curtis JT (1963) An ordination of the upland forest communities of southern Wisconsin. Ecol Monogr 27:325-349

Bush MV, Whittaker RH (1993) Non-equilibration in island theory of Krakatau. J Biogeogr 20:453-457

Camus PA (1990) Procesos regionales y fitogeografía en el Pacífico suroriental: el efecto de "El Niño-Oscilación del Sur". Rev Chil Hist Nat 63:11-17

Cerdá X, Retana J, Manzaneda A (1998) The role of competition by dominants and temperature in the foraging of subordinate species in Mediterranean ant communities. Oecologia 177:404-412

Chase JM, Leibold MA (2003) Ecological niches: linking classical and contemporary approaches. University of Chicago Press, Chicago

Clarke KR (1993) Non-parametric multivariate analyses of changes in community structure. Aust J Ecol 18:117-143

Connolly SR, Roughgarden J (1999) Theory of marine communities: competition, predation, and recruitment-dependent interaction strength. Ecol Monogr 69:277-296

Cowles TJ, Barber RT, Guillen O (1977) Biological consequences of the 1975 El Niño. Science 195:285-287

Dayton PK, Hessler RR (1972) Role of biological disturbance in maintaining diversity in the deep sea. Deep Sea Res II 19:199_ 208

Dayton PK, Tegner MJ, Edwards PB, Riser KL (1999) Temporal and spatial of kelp demography: the role of oceanographic climate. Ecol Monogr 69:219-250

DeBenedictis PA (1973) On the correlations between certain diversity indices. Am Nat 107:295-302

Diamond JM (1975) Assembly of species communities. In: Cody ML, Diamond JM (eds) Ecology and evolution of communities. Harvard University Press, Cambridge, pp 342-444

Dijkstra HA (2006) The ENSO phenomenon: theory and mechanisms. Adv Geosci 6:3-15

Escribano R, Daneri G, Farias L, Gallardo VA, Gonzalez HE, Gutierrez D, Lange CB, Morales CE, Pizarro O, Ulloa O, Braun M (2004) Biological and chemical consequences of the 19971998 El Niño in the Chilean coastal upwelling system: a synthesis. Deep Sea Res II 51:2389-2411

Fauchald K, Jumars PA (1979) The diet of worms: a study of polychaete feeding guilds. Oceanogr Mar Biol Ann Rev 17:193284

Fiedler PC (2002) Environmental changes in the eastern tropical Pacific Ocean: review of ENSO and decadal variability. Mar Ecol Prog Ser 244:265-283

Fox BJ (2001) The genesis and development of guild assembly rules. In: Weiher E, Keddy $\mathrm{P}$ (eds) Ecological assembly rules: perspectives, advances, retreats. Cambridge University Press, Cambridge, pp 23-56

Fuenzalida R, Blanco J, Nuñez R, Hormazábal S (1999) Efectos oceanográficos y meteorológicos durante El Niño 1997-98, en la zona de Iquique $\left(20^{\circ} \mathrm{S}\right)$. Rev Invest Cient Tecnol Ser Cien Mar 4:79-84
Gallardo VA (1985) Efectos del fenómeno de "El Niño" sobre el bentos sublitoral frente a Concepción, Chile. In: Arntz WE, Landa A, Tarazona J (eds) El Niño y su Impacto en la Fauna Marina. Instituto del Mar del Perú, Callao, pp 79-85

Gallardo VA, Palma M, Carrasco FD, Gutiérrez D, Levin LA, Cañete JI (2004) Macrobenthic zonation caused by the oxygen minimum zone on the shelf and slope off central Chile. Deep Sea Res II 51:2475-2490

Gaston GR (1987) Benthic polychaeta of the Middle Atlantic Bight: feeding and distribution. Mar Ecol Prog Ser 36:251-262

Glynn PW (1988) El Niño-Southern Oscillation 1982-1983: nearshore population, community, and ecosystem responses. Ann Rev Ecol Syst 19:309-345

Gotelli NJ, Colwell RK (2001) Quantifying biodiversity: procedures and pitfalls in the measurement and comparison of species richness. Ecol Lett 4:379-391

Gotelli, NJ, Entsminger JL (2006) EcoSim: null models software for ecology. Acquired Intelligence Inc. \& Kesey-Bear. http://www. garyentsminger.com/ecosim/ecosim.htm

Gutiérrez D, Gallardo VA, Mayor S, Neira C, Vásquez C, Sellanes J, Rivas M, Soto A, Carrasco F, Baltazar M (2000) Effects of dissolved oxygen and fresh organic matter on the bioturbation potential of macrofauna in sublittoral sediments off Central Chile during the 1997/1998 El Niño. Mar Ecol Prog Ser 202:81-99

Guzmán G, Soto R (2000) Camarones Peneidos (Decapoda, Dendrobranchiata) frente al norte de Chile: Evento "El Niño" 1997 1998. Not Mens Mus Nac Hist Nat Chile 343:12-14

Guzmán G, Nicosia W, Peredo R (1999) Cangrejos Portunidae (Crustacea, Decapoda) asociados al evento "El Niño" 1997 1998 en la zona norte de Chile, con el primer registro de Arenaeus mexicanus (G.). Not Mens Mus Nac Hist Nat Chile 388:4-6

Helly J, Levin LA (2004) Global distribution of naturally occurring marine hypoxia on continental margins. Deep Sea Res 51:11591168

Huston M (1979) A general hypothesis of species diversity. Am Nat 113:81-101

Jaksic FM (2001) Ecological effects of El Niño in terrestrial ecosystems of western South America. Ecography 24:241-250

Kruskal JB (1964) Non-metric multidimensional scaling: a numerical method. Psychometrika 29:115-129

Laudien J, Rojo M, Oliva M, Arntz WE, Thatje S (2007) Sublittoral soft bottom communities and diversity of Mejillones Bay in northern Chile (Humboldt Current upwelling system). Helgol Mar Res 61:103-116

Levin LA (2003) Oxygen minimum zone benthos: adaptation and community response to hypoxia. Oceanogr Mar Biol Ann Rev 41:1-45

Levin LA, Huggett CL, Wishner K (1991) Control of deep-sea benthic community structure by oxygen and organic-matter gradients in the eastern Pacific Ocean. J Mar Res 49:763-800

Levin LA, Blair NE, De Master DJ, Plaia G, Fornes W, Martin C, Thomas CJ (1997) Rapid subduction of organic matter by maldanid polychaetes on the North Carolina slope. J Mar Res 55:595-611

Levin LA, Blair NE, Martin CM, De Master DJ, Plaia G, Thomas CJ (1999) Macrofaunal processing of phytodetritus at two sites on the Carolina margin: in situ experiments using 13C-labeled diatoms. Mar Ecol Prog Ser 182:37-54

Levin LA, Gutiérrez D, Rathburn A, Neira C, Sellanes J, Muñoz P, Gallardo V, Salamanca M (2002) Benthic processes on the Peru margin: a transect across the oxygen minimum zone during the 1997-98 El Niño. Prog Oceanogr 53:1-27

McAuliffe JR (1984) Competition for space, disturbance, and the structure of a benthic stream community. Ecology 65:894-908 
McPhaden MJ (1999) Genesis and evolution of the 1997-98 El Niño. Science 283:950-954

Nyenzi B, Lefale PF (2006) El Niño Southern Oscillation (ENSO) and global warming. Adv Geosci 6:95-101

Philander SE (1990) El Niño, la Niña and the Southern Oscillation. Academic, San Diego

Quiroga E, Soto R, Rozbaczylo N (1999) Los poliquetos espiónidos (Polychaeta: Spionidae) y su importancia en la estructura de una comunidad: un caso de estudio en Bahía Iquique, norte de Chile $\left(20^{\circ} 11^{\prime} \mathrm{S}, 70^{\circ} 103^{\prime} \mathrm{W}\right)$. Gayana $63: 1-16$

Salzwedel H, Flores L, de Flores E.Ch, Zafra A, Carbajal G (1988) Macrozoobentos del sublitoral peruano, antes, durante y después de El Niño 1982-83. In: Salzwedel H, Landa A (eds) Recursos y Dinámica del Ecosistema de Afloramiento Peruano. Instituto del Mar del Perú, Callao, pp 77-98

Sanders HL (1968) Marine benthic diversity: a comparative study. Am Nat 102:243-282

Santos JM (2006) The impact of El Niño-Southern Oscillation events on South America. Adv Geosci 6:221-225

Shepard RN (1962) The analysis of proximities: multidimensional scaling with an unknown distance function. II. Psychometrika 27:219-246

Sielfeld W, Vargas M, Kong I (2003) Primer registro de Etropus ectenes Jordan, 1889, Bothus constellatus Jordan \& Goss, 1889, Achirus klunzingeri (Steindachner, 1880) y Symphurus elongatus (Günther, 1868) (Pisces, Pleuronectifiormes) en Chile, con comentarios sobre la distribución de los lenguados chilenos. Invest Mar Valparaíso 31:51-65

Sokolikhina EV, Semenov EK, Sokolikhina NN (2006) The atmospheric circulation on the synoptic scale during the culmination phase of the El-Niño-Southern Oscillation events (1997-1998). Adv Geosci 6:17-21

Stirling G, Wilsey B (2001) Empirical relationships between species richness, evenness, and proportional diversity. Am Nat 158:286299

Stone L, Roberts A (1990) The checkerboard score and species distribution. Oecologia 85:74-79

Stone L, Roberts A (1992) Competitive exclusion, or species aggregation? Oecologia 91:419-424

Strickland J, Parsons T (1972) A practical handbook of sea-water analysis. Bull Fish Res Bd Can 167:1-311

Tarazona J (1984) Modificaciones de la infauna bentónica de una bahía con deficiencia de oxígeno durante El Niño 1982-83. Rev Com Perm Pacífico Sur 15:223-238
Tarazona J, Arntz WE, Canahuire E, Ayala Z, Robles A (1985) Modificaciones producidas durante "El Niño" en la infauna bentónica de áreas someras del ecosistema de afloramiento peruano. In: Arntz WE, Landa A, Tarazona J (eds) El Niño y su Impacto en la Fauna Marina. Instituto del Mar del Perú, Callao, pp 55-63

Tarazona J, Salzwedel H, Arntz W (1988a) Oscillations of macrozoobenthos in shallow waters of the Peruvian central coast induced by El Niño 1982-1983. J Mar Res 46:593-661

Tarazona J, Salzwedel H, Arntz WE (1988b) Positive effects of "El Niño" on macrozoobenthos inhabiting hypoxic areas of the Peruvian upwelling system. Oecologia 76:184-190

Tarazona J, Arntz WE, Canahuire E (1996) Impact of two "El Niño" events of different intensity on the hypoxic soft bottom macrozoobenthos off the central Peruvian coast. Mar Ecol $17: 425-446$

Thagon Gl, Greene R (1992) Utilization of deposited and suspended particulate matter by benthic "interface" feeders. Limnol Oceanogr 37:1370-1391

Ulloa O, Escribano R, Hormazabal S, Quiñones RA, González RR, Ramos M (2001) Evolution and biological effects of the 1997-98 El Niño in the upwelling ecosystem off northern Chile. Geophys Res Lett 28:1591-1594

Vásquez JA, Alonso Vega JM, Buschmann H (2006) Long-term variability in the structure of kelp communities in northern Chile and the 1997-98 ENSO. J Appl Phycol 18:505-519

Yupanqui R, Quipúzcua L, Marquina R, Velazco F, Enriquez E, Gutiérrez D (2007) Composición y distribución del macrobentos en la Ensenada de Sechura, Piura, Perú. Rev Peru Biol 14:75-85

Weiher E, Keddy P (2001) Assembly rules as general constraints on community composition. In: Weiher E, Keddy P (eds) Ecological assembly rules: perspectives, advances, retreats. Cambridge University Press, Cambridge, pp 251-271

Whittam TS, Siegel-Causey D (1981) Species incidence functions and Alaskan seabird colonies. J Biogeogr 8:421-425

Wilson DS (1992) Complex interactions in metacommunities, with implications for biodiversity and higher levels of selection. Ecology 73:1984-2000

Zar JH (1999) Biostatistical analysis. Prentice-Hall, New Jersey 